\title{
MINERALOGICAL CONTRAINTS TO THE FORMATION OF VEIN-TYPE ZEOLITES FROM KIZARI AREA, THRACE NORTHERN GREECE
}

\author{
Voudouris P. ${ }^{1}$, Magganas A. ${ }^{1}$, Kati, M. ${ }^{1}$, Gerogianni N. ${ }^{1}$ \\ Kastanioti G. ${ }^{1}$, and Sakelaris, G. \\ ${ }^{1}$ University of Athens, Department of Mineralogy-Petrology, 15784 Athens, Greece \\ voudouris@geol.uoa.gr,amagganas@geol.uoa.gr,kati@geol.uoa.gr
}

\begin{abstract}
Vein-type zeolites in Kizari area, (western Thrace) are found within fresh to zeolitic altered volcanic rocks of andesitic to dacitic composition. The zeolites stilbite-Ca, Sr-bearing heulandite-Ca and laumontite occur in epithermal-style crustiform quartz/chalcedony-calcite veins crosscuting lavas and volcanic breccias. Open-space filling is common and well-shaped crystals (up to $3 \mathrm{~cm}$ ) were observed. Smectite, feldspar, magnetite, pyrite and rutile occur in minor amounts in the veins. Halite and barite grains are included in stilbite-Ca. SEM-EDS data indicate high Sr (up to $4.4 \mathrm{wt}$. \% SrO) and $\mathrm{Ba}$ (up to $2.9 \mathrm{wt}$. \% $\mathrm{BaO}$ ) contents for heulandite-Ca. It is suggested that the studied zeolites are intergral parts of the porphyry-epithermal mineralizing systems which operated in the area during the Oligocene. Their formation took place in the outmost transitional propylitic to fresh zones of the porphyry-epithermal systems and in a submarine environment as indicated by the geological and mineralogical evidence.
\end{abstract}

Key words: vein-type zeolites, stilbite-Ca, Sr-bearing heulandite-Ca, laumontite, submarine.

\section{Introduction}

Exploration activities during the last two decades in western Thrace resulted in the discovery of several zeolites deposits hosted mainly in Tertiary volcaniclastic rocks at Petrota, Pentalofos, Metaxades, Lefkimi, Ferres and Skaloma regions (Kossiaris et al., 1987; Marantos et al., 1989; Tsolis-Katagas \& Katagas, 1990; Karafoti \& Arikas, 1990; Tsirambides et al., 1989, 1993; Filippidis, 1993; Skarpelis et al., 1993, 1995; Kitsopoulos \& Dunham, 1994; Stamatakis et al., 1996, 1998; Kirov et al., 1999; Hall et al., 2000; Kassoli-Fournaraki et al., 2000; Marantos, 2004; Perraki \& Orfanoudaki, 2004; Filippidis and Kantiranis, 2005). The most common zeolites present in western Thrace are of HEU type (heulandite-clinoptilolite), but minor amounts of mordenite, analcime, stilbite and laumonite also occur. According to the above authors, the zeolites were formed from the alteration of volcanic glass, and are accompanied by clays, silica polymorphs (quartz, cristobalite), feldspars and calcite.

In addition, vein-type zeolites occur in a few localities (e.g. Virini, Feres, N. Santa and Vathi/Kilkis) (Michael et al., 1984; Filippidis et al., 1988; Marantos et al., 2004, 2007), and show similarities to hydrothermal zeolites found in many parts of the world (e.g. Ferroe islands/Danemark, Nova Scotia/Canada, Fassatal/Italy, Baical/Siberia, Andreasberg/Germany, Teschen/Czech Republik, Kongs- 
berg/Norway, Tergahorn/Island, Troodos Complex/Cyprus and Nasik, Poona/India (Extra Lapis, 2007).

Contrary to the papers published on the mineralogy, petrology and geochemistry of western Thracian zeolitized volcaniclastic deposits, there is limited information on the formation of vein-type zeolites in Thrace and in Greece in general. This study describes a new occurrence of vein-type zeolites in western Thrace, located within an andesite quarry at Kizari/Sapes in Rhodope prefecture, and present a model for their genesis based on mineralogical, mineral-chemical and geological data.

\section{Regional geology}

The geodynamic evolution of northeastern Greece includes an early oceanic-continental subduction/collision, growth of the thickness of the crust, and post-collisional extensional collapse of the orogen resulting in the formation of several supra-detachment basin-controlled volcanosedimenary formations from the Lutetian (48 - 43Ma) through the Oligocene up to the Pliocene (Krohe \& Mposkos, 2001; Papadopoulos \& Anastasiadis, 2003). Slab break-off and/or slab delamination were principal mechanisms for the generation of extensive post-collisional magmatism in the area (PePiper et al., 1998). The resulting plutonic-subvolcanic and volcanic rocks in Evros-Rhodopi region show calc-alkaline, high-K calc-alkaline, to shoshonitic affinity (Papavasiliou \& Sideris, 1984; Innocenti et al., 1984; Eleftheriadis, G., 1995; Christofides et al., 2004; Magganas et al. 2004). For the basic to intermediate and acid magma generation an enriched mantle source region, extensive differentiation within the crust, subordinate magma mixing and/or a partial melting of crustal material has been documented. The main phase of the Tertiary magmatism took place during the Oligocene and is represented by submarine/terrestrial volcanics and subvolcanic rocks associated with volcanosedimentary series composed of marls, sandstones, clays and intercalations of volcanic rocks (lavas, tuffs, pyroclastics).

Numerous porphyry $\mathrm{Cu}$-(Mo) and epithermal $\mathrm{Au}$-Ag-type systems formed during the Tertiary magmatic event in northeastern Greece, and are genetically related to microdiorite, microgranite, andesite and the dacite porphyries (Arikas \& Voudouris, 1998; Melfos et al., 2002). Faults and veins trending NW-SE, NE-SW and NNW-SSE influenced the distribution of magmatic rocks and spatially related magmatic-hydrothermal mineralization.

\section{Local Geology}

The Kizari area belongs to the eastern part of Komotini basin and also forms the northern extension of the eroded Tertiary volcanic edifice of Konos/Sapes: the Tertiary volcanosedimentary formations consist of M-U Eocene conglomerates, sandstones, marls, tuffs and tuffites, overlain by an Oligocene volcanic sequence dominating the entire area of Konos-Kizari (Fig. 1). The later consists of pyroclastics, lava flows and domes of andesitic to dacitic composition. Two types of intrusive stocks have been recognized in the broad area: an older, hydrothermally altered dacite stock with porphyry/epithermal-type mineralization at Konos area (Voudouris et al., 2006; Ortelli et al., 2009) and the $32 \mathrm{Ma}$ (Del Moro et al., 1988) quartz monzodiorite of Kirki. The majority of magmatic rocks in the Kizari-Konos area are hydrothermally altered as a result of repeated hydrothermal activity during the lifespan of the above mentioned porphyry-epithermal system. Alterations typical of both high-sulfidation- and low-sulfidation epithermal gold deposits are the products of interaction between rocks and fluids of acid and near-neutral to alkaline $\mathrm{pH}$ respectively (Voudouris, 1993). These alterations are fault-contolled and related mainly to the N-S and E-W trending faults in the area. The western part of the studied area is covered by the Silver Hill conglomerate (Shawh \& Constan- 


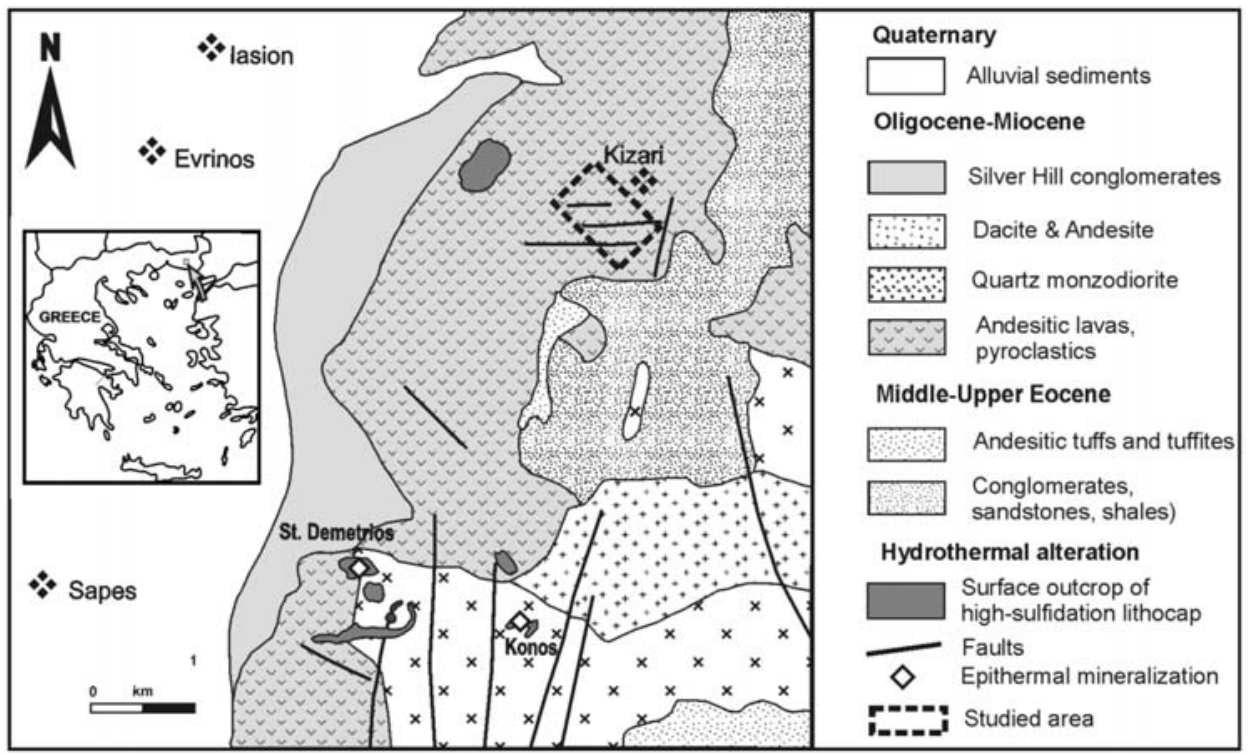

Fig. 1: Simplified geological map of Sapes-Kizari area and location of studied area (open square) (modified after Bitsios, 1973; Arikas, 1980; Greenwich Resources plc, 2004; Ortelli et al. 2009).

tinides, 2001), composed of angular to subrounded fragments of advanced argillic altered volcanic rocks and quartz-amethyst veins within an argillic matrix (Fig. 1). According to Shawh \& Constantinides (2001) the Silver Hill conglomerate represents a mass flow deposited marginal to the Komotini Graben during its subsidence.

\section{Description of the vein-type zeolite occurrences}

The dominant rock types in the studied area are pyroxene-hornblende-bearing andesites, as well as volcanic breccias. The zeolite-bearing veins are fault-related and occur within E-W and N-S trending veins, which crosscut andesitic lavas and volcanic breccias in the broad area (Fig. 2). Fresh andesitic lavas consist of plagioclase, clinopyroxenes and hornblende phenocrysts embedded within a groundmass (up to $70 \mathrm{vol}$ \%) containing microliths of the above minerals surrounded by a glassy matrix. Magnetite occurs both as phenocrysts and disseminated in the matrix. The volcanic breccias contain up to $\mathrm{dm}$ andesite angular to subrounded fragments within a fine-grained tuffitic matrix. The breccia fragments are identical to the above mentioned porphyritic lavas, whereas the matrix of the breccias is holocrystallie but finer grained compared to the fragments. Both the groundmass of the fragments and the matrix, consist of plagioclase and pyroxene microlithes, few K-feldspar and devitrification products of the glassy matrix.

The volcanic rocks are relatively fresh and only in the vicinity of the zeolite-bearing veins, are partially altered to smectite, pyrite, magnetite, calcite, silica polymorphs and zeolites. The above secondary minerals occur either finely disseminated in the groundmass or as replacement of the phenocrysts. The veins show typical epithermal structures as open space filling and crustification banding. They reach lengths of up to several meters and are up to $50 \mathrm{~cm}$ wide. Vein mineralogy greatly varies within the studied area and mainly two types of veins are distinguished: quartz-chalcedony \pm stilbite (Fig. 2b), and carbonate-rich stilbite-laumontite veins (Fig. 2c to f). The last vein- 

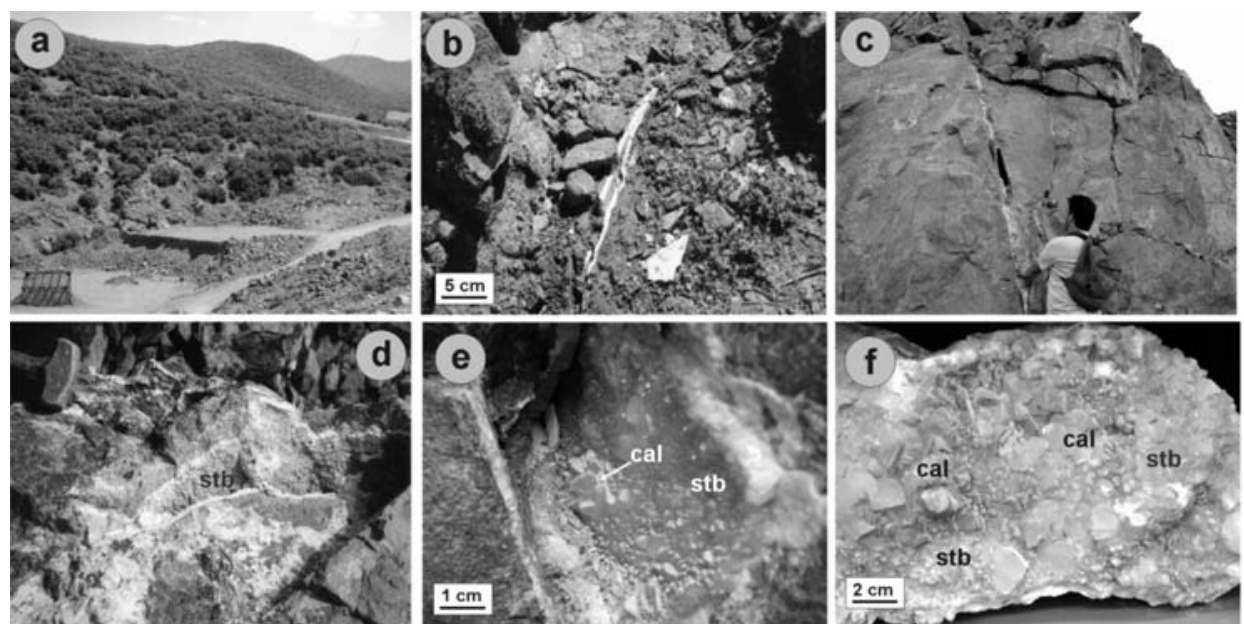

Fig. 2: (a) Panoramic view of lava quarry at Kizari (August 2006); (b) Chalcedony-stilbite veins crosscutting zeolitic altered lavas at Kizari (August 2006); (c) Stilbite-calcite veins with open-space filling crosscutting lavas (August 2009); (d, e) Stilbite (stb) and calcite (cal) filling fissures within lavas; (f) Hand-specimen with orange-colored stilbite (stb) and green-colored calcite (cal).

type may also be monomineralic (stilbite- or laumontite only) or may contain alternating bands with the above mentioned minerals. The quartz-chalcedony-rich veins (up to $5 \mathrm{~cm}$ wide) are banded with initial deposition of white-colored chalcedonic silica and final deposition of colourless chalcedony and fine-grained quartz. Open spaces are filled by pale orange to beige-colored idiomorphic stilbite crystals and very minor calcite.

In the carbonate-rich veins the silica polymorphs are missing and vein deposition starts with minorcalcite, followed by laumontite, stilbite and finaly by green-colored calcite (Fig. 2e, f). Hydrothermal breccias are common and consist of fragments of volcanic rocks surrounded by a stockwork of zeolite-bearing veinlets and veins.

\section{Methods}

Twenty three thin and polished thin sections of host rocks and zeolite assemblages were studied with an optical microscope and a JEOL JSM 5600 scanning electron microscope equipped with back-scattered imaging capabilities, at the Department of Mineralogy and Petrology, University of Athens, Greece. Analytical methods also included X-powder diffraction measurements obtained using a SIEMENS type D-500 diffractometer with $\mathrm{Cu}$ tube and Co filter at the Department of Mineralogy and Petrology, University of Athens, Greece. The definition of the studied zeolites is based on the nomenclatures for zeolite minerals proposed by Coombs et al. (1998).

\section{Mineralogy and mineral-chemistry}

\subsection{Zeolite minerals}

Stilbite: Stilbite with ideal formula $\mathrm{Na}, \mathrm{Ca}_{4}\left(\mathrm{Al}_{9} \mathrm{Si}_{27} \mathrm{O}_{72}\right) \cdot 30 \mathrm{H}_{2} \mathrm{O}$ is the most abundant mineral in the veins at Kizari quarry. It occurs in both silica- and carbonate-rich veins as euhedral crystals up to $3 \mathrm{~cm}$ 

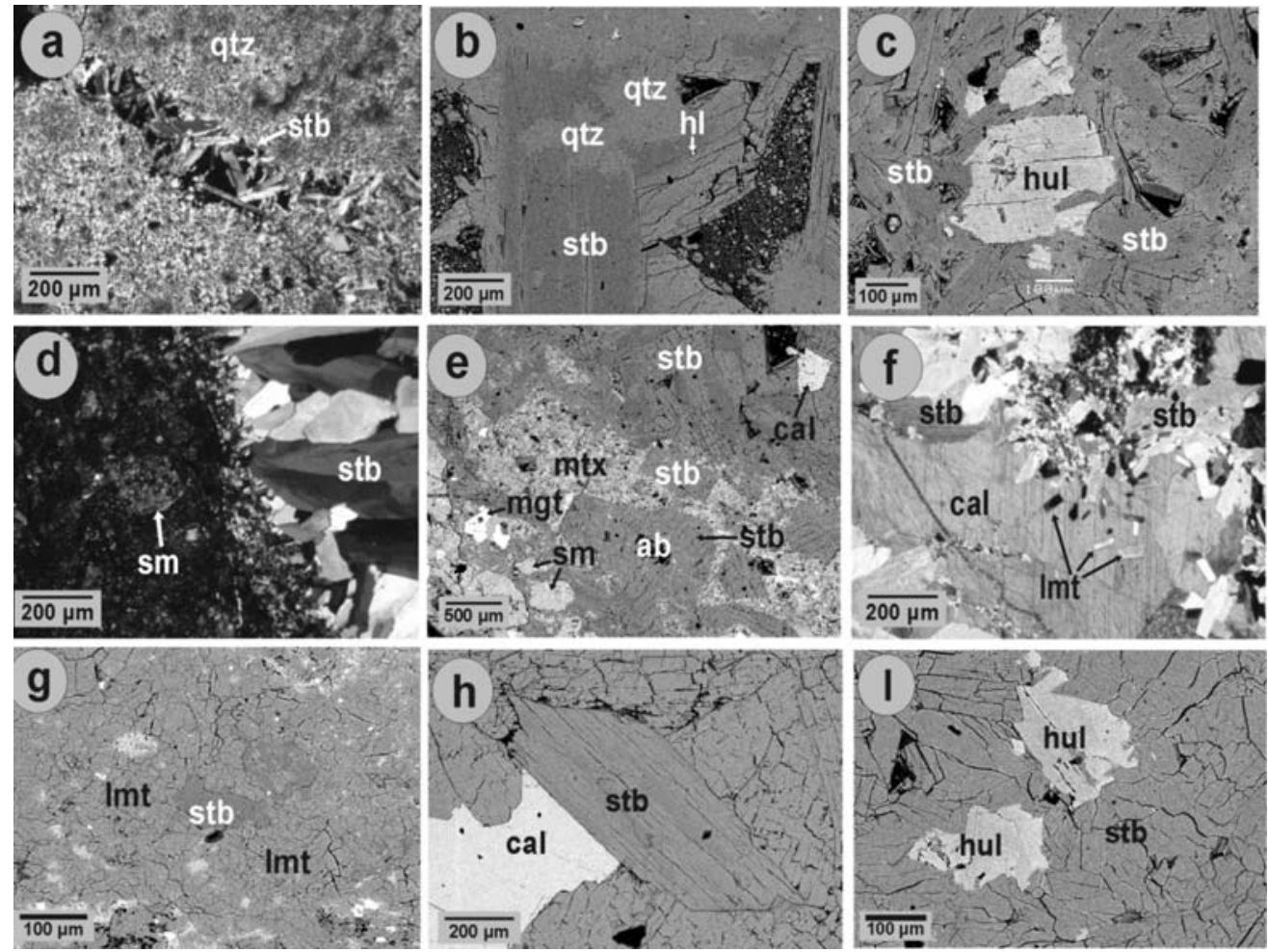

Fig. 3: Microphotographs of the quartz-chalcedony \pm stilbite veins (a-c) and carbonate-rich stilbite-laumontite veins (d-i) at Kizari (a) Stilbite (stb) filling vugs in quartz (qtz) veinlet (polariszing microscope image, +nicols); (b) Stilbite (stb) with halite (hl) inclusions, surrounds quartz (qtz) (SEM-BSE image); (c) Sr-bearing heulandite-Ca (hul) replaced by stilbite (stb) (SEM-BSE image); (d) Stilbite (stlb) veinlet in weakly altered andesite. Smectite (sm) is pseudomorph after pyroxene phenocrysts (polariszing microscope image, +nicols); (e) Stilbite (stb), smectite (sm), albite (ab) and magnetite (mgt) replace plagioclase and clinopyroxene phenocrysts of andesite and also occur in the recrystallized groundmass (mtx). Stilbite and calcite (cal) also occur in veinlets (SEM-BSE image); (f) Laumontite (lmt) postdates stilbite (stb) and is surrounded by calcite (cal) (polariszing microscope image, +nicols); (g) Laumontite (lmt) replaces stilbite (stb) (SEM-BSE image); (h) Idiomorphic stilbite (stb) crystals overgrown by calcite (cal) (SEM-BSE image); (i) Sr-bearing heulandite-Ca (hul) replaced by stilbite (stb) (SEM-BSE image).

with well developed $\{110\},\{010\}$ and $\{001\}$ faces. In the quartz-chalcedony veins stilbite postdates silica polymorphs deposition, and filling fractures and open spaces in quartz or is overgrown on quartz (Fig. 3a to c). It contains small inclusions of halite (Fig. 3b) and barite and also replaces Sr-Ba-bearing heulandite-Ca (Fig. 3c). In the carbonate-rich veins stilbite surrounds albite in pseudomorphs after plagioclase (Fig. 3e), replaces and is replaced by laumontite (Fig. 3g) and similarly to the quartz-chalcedony veins also replaces Sr-Ba-bearing heulandite-Ca (Fig. 3i). Stilbite is overgrown by calcite (Fig. 3f, h). Its composition is close to stochiometry with some $\mathrm{K}$ and $\mathrm{Sr}$ (up to 0.4 apfu) substituting for $\mathrm{Na}$ and $\mathrm{Ca}$ in the extra-framework sites (Table 1, Fig. 4). XRD patterns of stilbite are shown in Figure 5. 
Table 1. Representative EPMA data of laumontite (1-2), stilbite (3-6), heulandite (7-10) and smectite $(11-12)$

\begin{tabular}{|c|c|c|c|c|c|c|c|c|c|c|c|c|}
\hline & 1 & 2 & 3 & 4 & 5 & 6 & 7 & 8 & 9 & 10 & 11 & 12 \\
\hline $\mathrm{SiO}_{2}$ & 2.38 & 52.72 & 55.91 & 58.03 & 58.77 & 56.83 & 55.66 & 56.36 & 57.42 & 57.66 & 34.82 & 33.51 \\
\hline $\mathrm{Al}_{2} \mathrm{O}_{3}$ & .06 & 0.64 & 14.88 & 15.25 & 14.61 & 15.15 & 16.80 & 14.92 & 15.55 & 15.14 & 13.57 & 13.64 \\
\hline $\mathrm{Fe}_{2} \mathrm{O}_{3}$ & 0.09 & 0.18 & bd & $\mathrm{bd}$ & bd & $\mathrm{bd}$ & bd & $\mathrm{bd}$ & bd & bd & 18.10 & 19.27 \\
\hline $\mathrm{MgO}$ & 0.13 & 0.10 & 0.04 & $b d$ & 0.12 & $\mathrm{bd}$ & $\mathrm{bd}$ & $b d$ & $b d$ & $\mathrm{bd}$ & 18.77 & 18.67 \\
\hline $\mathrm{MnO}$ & 0.03 & 0.05 & 0.06 & $\mathrm{bd}$ & 0.07 & 0.01 & bd & 0.05 & 0.02 & bd & 0.31 & 0.23 \\
\hline $\mathrm{CaO}$ & 9.54 & 9.56 & 6.83 & 7.32 & 7.03 & 7.79 & 4.89 & 4.23 & 4.62 & 3.99 & 1.65 & 1.02 \\
\hline $\mathrm{Na}_{2} \mathrm{O}$ & 0.84 & 1.14 & 1.56 & 0.76 & 1.22 & 0.94 & 1.20 & 0.75 & 1.13 & 1.15 & 0.39 & 0.34 \\
\hline $\mathrm{K}_{2} \mathrm{O}$ & 0.72 & 0.69 & 0.52 & 0.08 & 0.24 & 0.03 & 0.53 & 1.02 & 0.59 & 1.33 & 0.14 & 0.18 \\
\hline $\mathrm{SrO}$ & 1.28 & 0.81 & 0.57 & 1.05 & 0.39 & 1.39 & 4.42 & 2.83 & 3.67 & 2.98 & 0.30 & 1.08 \\
\hline $\mathrm{BaO}$ & 0.01 & bd & bd & 0.01 & bd & $\mathrm{bd}$ & 1.27 & 2.89 & 0.75 & 1.56 & 0.11 & bd \\
\hline Total & 85.08 & 5.83 & 80.37 & 82.50 & 82.46 & 82.14 & 84.77 & 83.06 & 83.75 & 83.81 & 86.43 & 86.01 \\
\hline & $48(0)$ & $48(0)$ & $72(0)$ & $72(0)$ & $72(0)$ & $72(0)$ & $72(0)$ & $72(0)$ & $72(0)$ & $72(0)$ & $22(0)$ & $22(0)$ \\
\hline $\mathrm{Si}$ & 16.44 & 16.38 & 27.27 & 27.45 & 27.72 & 27.27 & 26.64 & 27.45 & 27.27 & 27.54 & 5.56 & 5.42 \\
\hline $\mathrm{Al}$ & 7.44 & 7.56 & 8.55 & 8.55 & 8.10 & 8.55 & 9.45 & 8.55 & 8.73 & 8.55 & 2.56 & 2.61 \\
\hline $\mathrm{Fe}$ & - & 0.06 & - & - & - & - & - & - & - & - & 2.17 & 2.34 \\
\hline $\mathrm{Mg}$ & 0.06 & 0.06 & - & - & 0.09 & - & - & - & - & - & 4.45 & 4.51 \\
\hline $\mathrm{Mn}$ & - & - & - & - & - & - & - & - & - & - & 0.06 & 0.03 \\
\hline $\mathrm{Ca}$ & 3.24 & 3.18 & 3.60 & 3.69 & 3.60 & 3.96 & 2.52 & 2.25 & 2.34 & 2.07 & 0.28 & 0.17 \\
\hline $\mathrm{Na}$ & 0.54 & 0.66 & 1.44 & 0.72 & 1.08 & 0.90 & 1.08 & 0.72 & 1.08 & 1.08 & 0.11 & 0.11 \\
\hline $\mathrm{K}$ & 0.30 & 0.30 & 0.36 & 0.09 & 0.18 & - & 0.36 & 0.63 & 0.36 & 0.81 & 0.03 & 0.03 \\
\hline $\mathrm{Sr}$ & 0.24 & 0.12 & 0.18 & 0.27 & 0.09 & 0.36 & 1.26 & 0.81 & 0.99 & 0.81 & 0.03 & 0.11 \\
\hline $\mathrm{Ba}$ & - & - & - & - & - & - & 0.27 & 0.54 & 0.18 & 0.27 & 0.00 & - \\
\hline
\end{tabular}

bd: below detection limit, Number of cations on the basis of oxygen $(\mathrm{O})$

Laumontite: Laumontite with ideal formula $\mathrm{Ca}_{4}\left(\mathrm{Al}_{8} \mathrm{Si}_{16} \mathrm{O}_{48}\right) \cdot 18 \mathrm{H}_{2} \mathrm{O}$ is a very common constituent at Kizari quarry. It is found in the matrix of hydrothermal breccias, surrounding angular fragments of andesites, and in the carbonate-rich stilbite veins. It forms white-colored acicular crystals (up to $1 \mathrm{~cm})$ with well-developed the $\{110\},\{100\}$ and $\{001\}$ faces. Laumontite predates and also postdates the deposition of stilbite-Ca. The chemistry of the analyzed laumontites is very close to the stoichiometric formula. The chemical analyses show a constant Si/Al ratio (Fig. 4). Small amounts of extra-framework cations (Na up to $0.7 \mathrm{apfu}, \mathrm{K}$ up to $0.3 \mathrm{apfu}$ and $\mathrm{Sr}$ up to $0.24 \mathrm{apfu}$ ) substitute for $\mathrm{Ca}$ (Table 1, Fig. 4). An XRD pattern of laumonite is shown in Figure 5b.

Heulandite: Heulandite series minerals with general formula $\left(\mathrm{Ca}_{0.5}, \mathrm{Sr}_{0.5}, \mathrm{Ba}_{0.5}, \mathrm{Mg}_{0.5}, \mathrm{Na}, \mathrm{K}\right)_{9}$ 

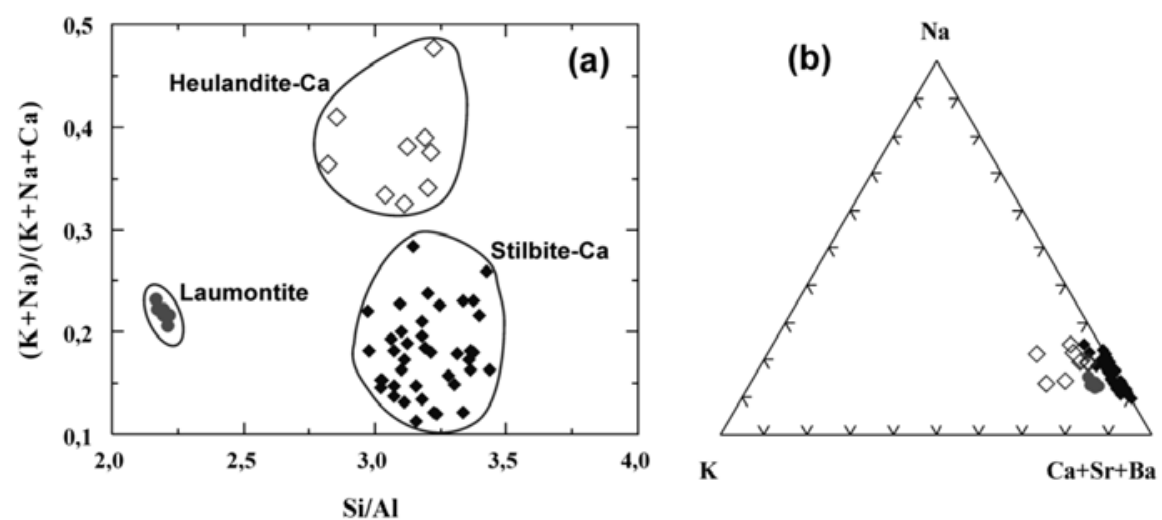

Fig. 4: Plot of zeolite compositions in terms of $(\mathrm{a})(\mathrm{K}+\mathrm{Na}) /(\mathrm{K}+\mathrm{Na}+\mathrm{Ca})$, and $(\mathrm{b})$ in the ternary $\mathrm{Na}-\mathrm{K}-(\mathrm{Ca}+\mathrm{Sr}+\mathrm{Ba})$ diagram.
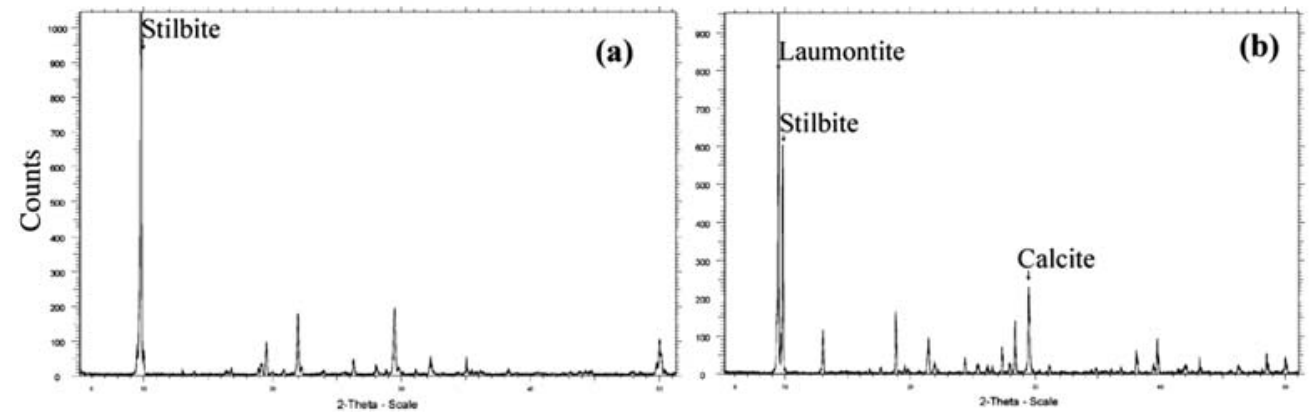

Fig. 5: X-ray diffractograms of (a) stilbite and (b) laumontite-stilbite-calcite association from Kizari.

$\left(\mathrm{Al}_{9} \mathrm{Si}_{27} \mathrm{O}_{72}\right) \cdot 24 \mathrm{H}_{2} \mathrm{O}$ display highly variable cation content, whereas $\mathrm{Ca}-, \mathrm{Na}-, \mathrm{K}-, \mathrm{Sr}$ - and $\mathrm{Ba}$-dominant compositions are known as heulandite-Ca, heulandite-Na, heulandite-K and heulandite-Sr and heulandite-Ba respectively (Coombs, et al. 1998; Larsen et al., 2005). Minerals with the same framework topology but with $\mathrm{Si}: \mathrm{Al} \geq 4.0$ are distinguished as clinoptilolites (Coombs et al., 1998). In both quartzchalcedony \pm stilbite, and carbonate-rich stilbite-laumontite veins heulandite occurs as inclusions (up to $400 \mu \mathrm{m}$ ) in stilbite (Figs 3c, i). The analyzed heulandites contain up to 1.2 apfu Na, 0.8 apfu K, 1.3 apfu $\mathrm{Sr}$ and 0.5 apfu Ba, and are characterized as Sr-Ba-rich heulandites-Ca (Table 1, Fig. 4).

\subsection{Smectite}

Smectite is a common constituent of the altered volcanics, forming pseudomorphs after pyroxene and hornblende, together with magnetite, pyrite, rutile, calcite and stilbite (Fig. 3d, e). It is also disseminated in the recrystallized groundmass. Representative chemical analyses are given in Table 1 . The analyzed smectites contain 13.9-18.77 wt. \% MgO (corresponding to 3.55-4.51 apfu Mg) and 16.1619.67 wt. \% FeO (2.03-2.83 apfu Fe).

\subsection{Carbonates, Sulfates}

In the carbonate-stilbite-laumontite veins, calcite postades zeolite deposition in open spaces (Fig. 3f, 
h). Calcite in green colored crystals up to $5 \mathrm{~cm}$ is common with both skalenohedral and rhombohedral habits present. In the quartz-chalcedony \pm stilbite veins minor calcite predates and also postdates quartz and stilbite deposition. In the volcanic wallrocks calcite occurs in phenocryst phudomorphs as well as finely disseminated in the groundmass. Microprobe analyses indicate very minor amounts of $\mathrm{Mn}, \mathrm{Fe}$ and $\mathrm{Mg}(<0.1$ wt. \%). Barite is present as small includions in stilbite crystals in the same veins.

\section{Discussion-Conclusions}

Zeolites occur in rocks of different mineralogical composition, age and geological environment. According to their mode of occurrence and formation environment, mainly two groups of zeolite occcurences have been distinguished (lijima 1980; Gottardi \& Galli, 1985; Hay and Sheppard 2001): (a) those formed under diagenesis to very low-grade metamorphism and (b) hydrothermal genesis. According to Hay (1966), Bargar \& Keith (1995), Chipera and Apps (2001), Sheppard and Hay (2001), Utada (2001), and Marantos et al. (2007), the formation and distribution of zeolites is controlled by three main factors: a) the composition of the hostrocks, b) the variation in temperature and pressure, and c) the chemistry of pore water. In general, zeolites are formed under relatively high activity of alkalies and alkali earth elements and high $\mathrm{pH}$ values.

Recent studies on southeastern Rhodope zeolites in Bulgaria and Greece suggested a hydrothermal model, where the zeolitization of the volcaniclastic rocks was caused by low-temperature open hydrothermal systems in a shallow-marine environment (Raynov et al., 1997; Sheppard and Hay, 2001; Yanev et al., 2006; Marantos et al., 2007).

The present study describes stilbite-Ca, Sr-bearing heulandite-Ca and laumontite in euhedral crystals up to $3 \mathrm{~cm}$ associated with smectite, albite, magnetite, pyrite and rutile, within epithermal-style crustiform quartz/chalcedony-calcite veins crosscuting lavas and breccias. Based on geological, petrographical, mineralogical and geochemical data the studied zeolites are of hydrothermal origin and can be regarded as integral parts of the porphyry/epithermal systems in the area. The Kizari zeolites are considered to have been formed in the transitional zone between propylitic alteration and fresh rocks and in a submarine environment as indicated by the presence of halite. The fluids were supersaturated in $\mathrm{SiO}_{2}$ as can be deduced from the presence of chalcedony and quartz in vugs and veins of the rocks. The observed rhythmic zoning suggests alternated/repeated deposition of zeolites, calcite and smectite at several stages.

The chemical composition of zeolites at Kizari (Ca-dominant) and the absence of Na-rich zeolites (e.g. analcime) may suggest a deeper environment of formation, since at depth the impact of sea water with $\mathrm{Na}$ as the main constituent was rather low during zeolitic alteration as in similar zeolite occurrences in basic igneous rocks of Troodos Complex, Cyprus (Dill et al., 2007). The formation of laumontite and stilbite at Kizari may be resulted from the nature of the hydrothermal fluids, which were more enriched in $\mathrm{Ca}, \mathrm{Ba}$ and $\mathrm{Sr}$. Minor $\mathrm{K}$ and $\mathrm{Na}$ amounts in the zeolites at Kizari, are derived from glass present in the groundmass of the volcanics. Laumontite and stilbite formation together with albite is attributed to Ca release during breakdown of plagioclase in the rocks. In addition calcium released by the decomposition of An-rich plagioclase was taken up by calcite. This mechanism is also proposed for the laumontite-stilbite association present in stockwork-like zeolitization in the basic igneous rocks of the Troodos Complex (Dill et al., 2007). According to Dill et al. (2007), laumontite is formed at low $\mathrm{PH}_{2} \mathrm{O}$, whereas at higher $\mathrm{PH}_{2} \mathrm{O}$ stilbite may crystallize according to the following reactions: anorthite + quartz $+4 \mathrm{H}_{2} \mathrm{O} \rightarrow$ laumontite and anorthite + quartz $+7 \mathrm{H}_{2} \mathrm{O} \rightarrow$ stilbite. The studied zeolites were formed at relatively low temperatures $\left(<140^{\circ} \mathrm{C}\right)$, since stilbite coexists with heulandite and laumontite between 110 and $120^{\circ} \mathrm{C}$ (Bargar 1994), and in the Troodos Complex 
stilbite has derived from laumontite as temperature and pressure dropped below about $140{ }^{\circ} \mathrm{C}$ (Dill et al. 2007). In zoned sequences of zeolites in amygdales and veins in the North Mountain Basalt, Nova Scotia, the succession of mordenite $\rightarrow$ heulandite $\rightarrow$ stilbite are interpreted as developing under falling temperatures by active hydrothermal circulation (Pe-Piper, 2000).

The amount of the Kizari zeolites is not feasible for exploitation, however the broad area should be considered as target for future exploration. Under consideration of their abundant zeolitic veins and alteration, the quarried lavas are probably not much suitable materials for construction purposes. Nevertheless, the studied zeolites may provide valuable mineralogical specimens suitable for museum collections and educational purposes. Based on this assumption, the Kizari quarry should be protected and considered as a visiting site in a broad Mineralogical-Petrological geotope in Rhodopi region.

\section{References}

Arikas, K., 1980. Geologische und petrographische Untersuchungen in Umbebung von Kirki (Thrazien, Griechenland), Mitteilungen aus dem Geologish-Paläontologischen Institut der Universität Hamburg, 49, 1-26.

Arikas, K., and Voudouris, P., 1998. Hydrothermal alterations and mineralizations of magmatic rocks in the southern Rhodope Massif. Acta Volcanologica, 10, 353-365.

Bargar, K.E., 1994. Hydrothermal alteration in the SUNEDCO 58-28 geothermal drill hole near Breitenbush Hot Springs, Oregon. Oregon Geol. Soc., 56, 75-87.

Bargar, K.E. and Keith, T.E.C., 1995. Calcium zeolites in rhyolitic drill cores from Yellowstone national park, Wyoming. In D.W. Minga, and F.A. Mumpton (eds), Natural Zeolites, International Committee on Natural Zeolites, Brockport, New York, 69-86.

Bitsios, D., 1973. La géologie et métallogenie de la région de Kirki (Thrace Occidentale - Grèce). Thèse 3. Cycle, Univ. Paris VI, 100pp.

Chipera, S.J., and Apps, J.A., 2001. Geochemical stability of natural zeolites. In D.L. Bish and D.W. Ming (eds) Natural Zeolites: Occurrence, Properties, Applications. Rev. Mineral. Geochem., Mineralogical Society of America and the Geochemical Society, 45, 117-161.

Christofides, G., Pecskay, Z., Soldatos, T., Eleftheriadis, G., and Koroneos, A., 2004. The Tertiary Evros volcanic rocks (Greece): Petrology, K/Ar geochronology and volcanism evolution. Geologica Carpathica, 55, 397-409.

Coombs, D.S., Alberti, A., Armbruster, T., Artioli, G., Colella, C., Galli, E., Grice, J.D., Liebau, F., Mandarino, J.A., Minato, H., Nickel, E.H., Passaglia, E., Peacor, D.R., Quartieri, S., Rinaldi, R., Ross, M., Sheppard, R.A., Tillmanns, E., Vezzalini, G., 1998. Recommended nomenclature for zeolite minerals: Report of the Subcommittee on Zeolites of the Mineralogical Assiciation, Commision on New Minerals and Mineral Names. European Journal of Mineralogy, 10, 1037-1081.

Del Moro, A., Innocenti, F., Kyriakopoulos, C., Manetti, P. and Papadopoulos, P., 1988. Tertiary granitoids from Thrace (Northern Greece): Sr isotopic and petrochemical data. Neues Jahrbuch für Mineralogie Abhandlungen, 159, 113-135.

Dill, H.G., Füssl, M., and Botz, R., 2007. Mineralogy and (economic) geology of zeolite-carbonate mineralization in basic igneous rocks of the Troodos Complex, Cyprus. Neues Jahrbuch für Mineralogie Abhandlungen, 183, 251-268.

Eleftheriadis, G., 1995. Petrogenesis of the Oligocene volcanics from the Central Rhodope massif (N. Greece). European Journal of Mineralogy, 7, 1169-1182.

Extra Lapis 2007. Zeolithe. Mineralien-zugleich nützlich und wunderschön, Christian Weise Verlag, 
München, 97pp.

Filippidis, A., 1993. New find of moissanite in the Metaxades zeolite-bearing volcaniclastic rocks, Thrace county, Greece. Neues Jahrbuch für Mineralogie Monatshefte, 11, 521-527.

Filippidis, A., Kougoulis, C., Michailidis, K., 1988. Sr-bearing stilbite in a quartz-monzonite from Vathi, Kilkis, Northern Greece. Schweizerische Mineralogische und Petrographische Mitteilungen, 68, 67-76.

Filippidis, A., and Kantiranis, N., 2005. Industrial, agricultural and environmental uses of the natural zeolites of Thrace. Bull. Geol. Soc. Greece, 37, 90-101.

Gottardi, G., and Galli, E., 1985. Natural Zeolites. Springer-Verlag, Berlin, Germany, 409pp.

Greenwich Resources plc (2004) The Sapes project - simplified regional geology.

Hall, A., Stamatakis, M., and Walsh, J.N., 2000. The Pentalofos zeolitic tuff formation: a giant ino-exchange column. Annales Geologiques des Pays Helleniques, 38, 175-192.

Hay, R.L., 1966. Zeolite and zeolite reactions in sedimentary rocks. Geological Society of America Special Paper, 85, 130pp.

Hay, R.L., Sheppard, R.A., 2001. Occurrence of zeolites in sedimentary rocks: An overview. In D.L. Bish and D.W. Ming (eds), Natural zeolites: occurrence, Properties, Applications, Rev. Mineral. Geochem., Mineralogical Society of America and the Geochemical Society, 45, 217-234.

Iizima, A., 1980. Geology of natural zeolites and zeolitic rocks. Pure and Applied Chemistry, 52, 2115-2130.

Innocenti, F., Kolios, N., Manetti, O., Mazzuoli, R., Peccerillo, G., Rita, F., and Villari, L., 1984. Evolution and geodynamic significance of the Tertiary orogenic volcanism in northeastern Greece. Bulletin of Volcanology, 47, 25-37.

Karafoti, M. and Arikas, K. 1990. Petrography and geochemistry of Tertiary volcanic rocks between Lutra and Fere (Thrace, Northeastern Greece). Geologica Rhodopica, 2, 227-240.

Kassoli-Fournaraki, A., Stamatakis, M., Hall, A., Filippidis, A., Michailidis, K., Tsirambides, A., and Koutles, Th., 2000. The Ca-rich clinoptilolite deposit of Pentalofos, Thrace, Greece. In C Collela and F.A. Mumpton (eds), Natural Zeolites for the Third Millenium, DeFreda Editore, Naples, Italy 193-202.

Kirov, G.N., Filippides, A., Tsirambidis, A., Tzvetanov, R.G. and Kassoli-Fournaraki, A., 1999. Zeolitebearing rocks in Petrota area (Eastern Rhodope Massif, Greece). Geologica Rhodopica, 2, 500-511.

Kitsopoulos, K., Dunham, A., 1994. Application of zeolitic volcanic tuffs from Greece (LefkimiDadia, Metaxades and Santorini island, Greece, as pozzolanic materials. Bull. Geol. Soc. Greece, 30, 323-333.

Koshiaris, G., Karantassi, S. and Gregoriades, G., 1987. Zeolite Occurrences in West Thrace. I.G.M.E. Internal report, 30pp.

Krohe, A., and Mposkos, E., 2001. Structural evolution and exhumation history of the Rhodope UHP-HP metamorphic province (Northern Greece). Bull. Geol. Soc. Greece, 34, 75-82.

Larsen, A.O., Nordrum. F.S., Döbelin, N., Armbruster, T., Petersen, O.V., and Erambert, M., 2005. Heulandite-Ba, a new zeolite species from Norway. European Journal of Mineralogy, 17, 143-153.

Magganas A., Kyriakopoulos K.,. Sideris C. and Eleftheriadis G., 2004. Petrological and Geochemical Variations of the Tertiary Convergent Volcanism in North-Eastern Greece. Annales Geologiques des Pays Helleniques, 40, 99-116.

Marantos, I., Kosharis, G., Karantassi, S. and Gregoriades, G., 1989. A study on zeolitic alteration of Tertiary pyroclastics from Metaxades area, Evros county, Greece. Bull. Geol. Soc. Greece, 23, 443-450. 
Marantos, I., Koshiaris, G., Karantassi, S., Perdikatsis, V. and Christidis, G., 2004. Preliminary study of altered Tertiary volcaniclastic rocks in the area of Asproula, Nea Santa, Rodopi perfecture, Thrace, NE Greece. Bull. Geol. Soc. Greece, 35, 454-463.

Marantos, I., 2004. Study of the Tertiary volcanic rocks alteration in the Feres basin of Evros prefecture, emphasizing on the genesis of zeolites and their possible applications. $\mathrm{PhD}$ thesis, Technical University of Crete, Department of Mineral Research Engineering, Chania, Greece. 264pp.

Marantos, I., Markopoulos, T., and Christidis, G.E., 2007. Zeolitic alteration in the Tertiary Feres volcanosedimentary basin, Thrace, NE Greece. Mineralogical Magazine, 71, 327-345.

Melfos, V., Vavelidis, M., Christofides, G., and Seidel, E. 2002. Origin and evolution of the Tertiary Maronia porphyry copper-molybdenum deposit, Thrace, Greece. Mineralium Deposita 37, 648-668.

Michael, K., Dimitriades, A., Mastrogiannidou, K., and Angelopoulos, A. 1984. Ore deposits study at Virini-Pessani-Lefkimi area, Evros prefecture, IGME internal report, 64pp (in Greek).

Ortelli, M., Moritz, R., Voudouris, P., Spangenberg, J., 2009. Tertiary porphyry and epithermal association of the Sapes-Kassiteres district, eastern Rhodopes, Greece, In Williams et al. (eds) Smart Science for exploration and mining, Proc. of the 10 ${ }^{\text {th }}$ Biennial SGA meeting, Townsville, 536-538.

Papadopoulos, P., and Anastasiadis, I., 2003. Geology of Tertiary basins of SE Rhodope, Thrace. IGME internal report, $20 \mathrm{pp}$. (in Greek).

Papavasiliou, K.T, and Sideris, K., 1984. Geochemistry and mineralogy of Tertiary lavas of Sappai-Ferrai area (W-Thrace)-Greece. Implications on their origin. IGME - Geochemical Research, 4, 21pp.

Pe-Piper, G., 2000. Mode of occurrence, chemical variation and genesis of mordenite and associated zeolites from the Morden area, Nova Scotia, Canada. Canadian Mineralogist, 38, 1215-1232.

Pe-Piper, G., Christofides, G., and Eleftheriadis, G., 1998. Lead and neodymium isotopic composition of Tertiary igneous rocks of northeastern Greece and their regional significance. Acta Volcanologica, 10, 255-263.

Perraki, T., and Orfanoudaki, A., 2004. Mineralogical study of zeolites from Pentalofos area, Thrace, Greece. Applied Clay Science, 25, 9-16.

Raynov, N., Popov, N., Yanev, Y., Petrova, P., Popova, T., Hristova, V., Atanasova, R. and Zankarska, R. 1997. Geological, mineralogical and technological characteristics of zeolitized (clinoptilolitized) tuff deposits in the Eastern Rhodopes, Bulgaria. In G. Kirov, L. Filizova and O. Petrov (eds), Natural zeolites - Sofia '95. Pensoft, Sofia, 263-275.

Shawh A.J, Constantinides D.C, 2001. The Sappes gold project. Bull. Geol. Soc. Greece 34, 1073-1080.

Sheppard, R.A. and Hay, R.L., 2001. Formation of zeolites in open hydrologic systems. In D.L. Bish and D.W. Ming (eds). Natural Zeolites: Occurrence, Properties, Applications. Rev. Mineral. Geochem., Mineralogical Society of America and the Geochemical Society, 45, 261-276.

Skarpelis, N., Marantos, I., Christidis, G., 1993. Zeolites in Oligocene volcanic rocks, Dadia-Lefkimi area, Thrace, Northern Greece: Mineralogy and cation exchange properties, Bull. Geol. Soc. Greece, 28, 305-315.

Stamatakis, M., Hall, A., Hein, J.R, 1996. The zeolites deposits of Greece. Mineralium Deposita, 31, 473-481.

Stamatakis, M., Hall, A., Lutat, U., and Wlsch, J.N. 1998. Mineralogy, origin and commercial value of the zeolite-rich tuffs in the Petrota-Pentalofos area, Evros county, Greece. Estudios Geologicos, 54, 3-15.

Tsirambides, A., Kassoli-Fournaraki, A., Filippidis, A., and Soldatos, K. 1989. Preliminary results on clinoptilolite-containing volcaniclastic sediments from Metaxades, NE Greece. Bull. Geol. Soc. Greece, 23, 451-460. 
Tsirambides, A., Filippidis, A., and Kassoli-Fournaraki, A., 1993. Zeolitic alteration of Eocene volcaniclastic sediments at Metaxades, Thrace, Greece. Applied Clay Science, 7, 509-526.

Tsolis-Katagas, P., and Katagas, C., 1990. Zeolitic diagenesis of Oligocene pyroclastic rocks of Metaxades area, Thrace, Greece. Mineralogical Magazine, 54, 95-103.

Voudouris, P., 1993. Mineralogical, geochemical and fluid inclusion studies on epithermal vein type goldsilver mineralizations at Kassiteres/Sapes, (NE-Greece). Ph.D. thesis, Univ. Hamburg, 218pp.

Voudouris, P., Tarkian, M., Arikas, K., 2006. Mineralogy of telluride-bearing epithermal ores in Kassiteres-Sappes area, western Thrace, Greece. Mineralogy and Petrology, 87, 31-52.

Utada, M., 2001. Zeolites in hydrothermally altered rocks In D.L. Bish and D.W. Ming (eds). Natural zeolites: Occurrence, properties, applications. Rev. Mineral.Geochem., Mineralogical Society of America and the Geochemical Society, 45, 305-319.

Yanev, Y., Cochemé J.J., Ivanova R., Grauby, O., Burlet E., and Pravchnska, R., 2006. Zeolites and zeolitization of acid pyroclastic rocks from paroxysmal Paleogene volcanism, Eastern Rhodopes, Bulgaria. Neues Jahrbuch für Mineralogie Abhandlungen, 182, 265-283. 
